\title{
Knowledge and Perception of Muslim and Non-Muslim Customers Towards Islamic Banking
}

\author{
Ira Eka Pratiwi*
}

Fachrudin Fiqri Affandy ${ }^{* *}$

Received: 23.02 .2020

Accepted: 21.10 .2020

DOI: $10.25272 /$ ijisef.693027

Type: Research Article

\begin{abstract}
In the past few decades, Islamic banking has gained popularity not only in Muslim countries but also in non-Muslim countries. This is due to the fact that the products and services provided by Islamic banking are not only intended for Muslims but also non-Muslims. As one of the largest Muslim population countries in the world, Indonesia has the potential to develop its Islamic banking. However, not all Indonesians have the same level of knowledge and perceptions about Islamic banking. Therefore, it will turn out to be an obstacle to Islamic banking growth in the future. This research is conducted to investigate the knowledge and perception of Muslim and non-Muslim about the products and services provided by Islamic banking in Papua Province, one of the regions in Indonesia with a minority Muslim population. Using the questionnaire to collect the data from 452 Muslim respondents and 231 non-Muslim respondents, the result showed that there is a correlation between religion and knowledge as well as religion and understandings of Islamic banking products, services, and operational activities. Furthermore, this study also reveals that both Muslims and nonMuslims have a good and positive perception of Islamic banking.
\end{abstract}

Keywords: Islamic banking, Knowledge, Perception, Muslim, Non-Muslim, Papua

Jel Codes: G29, G40, G53

\footnotetext{
* Researcher and Lecturer, Faculty of Islamic Economics and Business, Fattahul Muluk Papua State Islamic Institution. Email: irax23@yahoo.com, ORCID: 0000-0002-3583-4094

** Researcher and Lecturer, Faculty of Islamic Economics and Business, Fattahul Muluk Papua State Islamic Institution. Email: affandyjo@gmail.com, ORCID: 0000-0003-1991-266X
} 


\section{Introduction}

The development of the Islamic financial system in Indonesia began since the establishment of Bank Muamalat Indonesia in 1991 as the first Islamic bank in Indonesia and began operating officially in 1992. However, at the beginning of its development, Islamic banking did not show a good performance as well as conventional banking. Rivai (2010) states that this is due to the regulation of Islamic banking that have not been well organized.

Anwar (2016) argues that Indonesia is lagged behind in the preparation of special regulations for Islamic banking when compared to Malaysia. It is due to the Islamic banking regulations in 1992 was only based on Indonesia Banking Act No.7 in 1992 and Government Rules No.72 in 1992. Meanwhile, the Malaysian government had prepared a special set of regulations regarding Islamic banking since 1983. However, since the implementation of the Banking Act No.10 of 1998 replaced the Banking Act No.7 of 1992, the development of Islamic banking started to change better. With the issuance of this regulation, Islamic banking was introduced to the public at large.

One of the most impressive things about Islamic banking is its resistance to the global economic crisis. The Central Bank of Indonesia explained that despite the financial crisis in 2008, the performance of Islamic banking in 2009 continued to show high performance, in addition to the channeling of funds carried out by Islamic banks consistently increasing. The Central Bank of Indonesia also stated that Islamic banking is one of the pillars supporting national financial system stability.

Islamic banking in Indonesia increasingly shows its existence with the enactment of Law No.21 of 2008 concerning Islamic Banking. It provides legal certainty and an adequate foundation to encourage its growth more quickly. One of the characteristics of Islamic Banking growth is the increase in the number of sharia commercial banks and sharia business units. According to the Financial Service Authority (2011), the Data of Sharia Banking Statistics shows that in 2008 there were only 5 Sharia Commercial Banks in Indonesia with 581 offices spread throughout Indonesia. Meanwhile, there were also 27 conventional commercial banks that run sharia business units with 241 offices spread throughout Indonesia. This number continues to increase until 2012 and 2017. Until August 2018, the data shows that currently there are 13 Sharia Commercial Banks, 21 Sharia Business Units and 101 Rural Banks in Indonesia.

However, with the increase in the number of Islamic commercial banks and sharia units which are expected to reach wider communities and increase fund mobilization, this does not directly indicate the high growth of Islamic banking. In terms of asset growth, data from the Financial Services Authority said that until the end of June 2018, the total assets of Islamic banking had only reached $5.70 \%$ of the total assets of national banks. Comparing to the potential of Indonesia, which has majority Muslim population, the value is still very low (OJK, 2018). According to Chairman of the Commissioners Board of Financial Service Authority Muliaman D. Hadad, this could be caused by a lack of penetration of Islamic 
financial products where Islamic banking needs to intensively issue superior products. In addition, the results of OJK's survey in 2016 regarding the Islamic financial Inclusion and Islamic Financial Literacy indicates that the knowledge and understanding of the Indonesian people regarding Islamic products and finance are still very low. The results show that the Islamic Financial Inclusion index in Indonesia was only $11.06 \%$. Likewise, the Islamic Financial Literacy index is only $8.11 \%$. According to Umar (2017), generally, the Islamic Financial Inclusion in Indonesia is low. He suggests that the community do not fully use formal financial services as the main source of finance and financing.

According to the OJK's survey (2016), Papua is one of the regions that have the lowest Islamic Financial Literacy index and Islamic Financial Inclusion index in Indonesia. The index of Islamic Financial Literacy in Papua is $1.09 \%$ and the index of Islamic Financial index is $5.82 \%$. Papua Province is located in the eastern part of Indonesia. Although demographically the majority of Papua citizen are Christian, currently there are several Islamic Banking operates in Papua regions. It is due to the universality of Islamic Banking which provides an equal service both for Muslim and non-Muslims costumers. The data of Sharia Banking Statistics reported that until the end of September 2018, there are 7 Sharia commercial banks in Papua.

This paper attempts to explore the level of knowledge and perceptions of Muslim and nonMuslim in Papua towards Islamic Banking service and products. Therefore, there are several questions, namely: 1) is there any correlation between religion and the knowledge of Islamic banking in Papua regarding Islamic banking? 2) What is the understanding of Muslim and non-Muslim in Papua regarding the products, services, and operational system of Islamic banking? What are the perceptions of Muslim and non-Muslim in Papua towards Islamic banks?

\section{Literature Review}

The level of Islamic financial literacy of each community in Indonesia varies, including their knowledge of Islamic financial product features, uses, risks, sources of information, and financial goals. There are several studies that have been conducted to analyze knowledge and attitudes of the community towards Islamic banking. One of them is carried out by Rahman (2012) which investigated the attitude of Muslims towards Islamic banking in the North West of England using community-based research approach. The collected the primary data by survey questionnaire and semi-structured interview which found that the Islamic financial system has enormous opportunities and potential to achieve economic growth in the UK. In addition, the Islamic finance system can also create financial stability, build a multicultural society Meanwhile, Soud and Sayilir (2017) analyzed the perception among Muslims and non-Muslims in Tanzania towards Islamic Banking suggested that there are significant differences between the perceptions of Muslim and non-Muslim communities regarding Islamic banking in Tanzania. Moreover, the also concluded that 
there are differences in factors that influence Muslims and non-Muslims to a bank account in Islamic banks.

Abdullah, Sidek and Adnan (2012) examined the perception of non-Muslim costumers of Islamic banking services and products in Malaysia. They found that even though Islamic banking services are gaining popularity in non-Muslims costumer, the level of knowledge on Islamic banking has to be increased. On the other hand, the study also suggested that non-Muslim customers in Malaysia are unsure about the future development of Islamic banking, although most of the customers strongly believe that Islamic banking will take control the banking industry in Malaysia. In addition, Kaakeh, Hassan and Almazor (2018) found that the determinants of the intention to use Islamic banking are attitude, religious motivation and awareness. They also suggest that the potential Islamic banking costumer in Spain base on their religion (Muslim), gender (Male), and education (did not reach university). Several other studies also have been conducted by the following researchers which are shown in table 1. Other previous studies such as conducted by Hossain and Roy (2017); Wan Omar and Rahim (2015) also investigates the non-Muslim perception on Islamic banking using quantitative method, which is concluded that the the non-Muslim has a positive perception thus correlate with the reception of Islamic banking. Several other studies also have been conducted to investigate the perception of the consumer both Muslim and non-Muslim towards Islamic banking, such as by Akber, Shah, and Kalmadi (2012); Ringim (2014); Buchari, Rafiki, and Qassab (2015); Saiti (2015); Chaouch (2017); Ul Islam and Rahman (2017).

The novelty and difference of this study with the previous studies is in the variable used. Firstly, this study investigate the perception of Muslim and non-Muslim customers based b their knowledge and understanding towards the product, service, and operational system of Islamic banking. Also, this study is conducted in a non-Muslim majority area in Indonesia, Papua Province, which has a low level of financial literation index. Besides, this research is one of the few studies conducted in this province regarding the perception of the consumers on Islamic banking.

\section{Research Methodology}

This study uses a quantitative approach. The population used in this study is the Muslim and non-Muslim costumers of Islamic banking in Papua province, mainly they are who lived in Jayapura city, Jayapura Regency and Kerom District. Meanwhile, a total of 683 respondents is used in this study as the research sample. According to Tabachink and Fidell (2013), the sample size needed in a study using formula of " $N>50+8 m$ " where is " $N$ " is the number of sample and " $\mathrm{m}$ " is the number of independent variables (Bujang et al., 2017). Meanwhile, according to Roscoe (1975), the sample size that is feasible in a study is 30-500 samples (Ferdinand, 2005). In addition, the sampling method used in this study was nonprobability sampling, which was a randomly selected sampling technique. Elements of the 
population selected as samples can be caused by accident or due to other factors that have been previously planned by the researcher.

The primary data used in this study is collected by using a questionnaire which is divided into three parts. The first part of the questionnaire is the demographic profile of the respondents consisting of age, gender, religion, marital status, education level and income level. The second part consists of knowledge, understanding of the Islamic banking operational system, and perceptions of Islamic banks. The answer given is measured using a Likert scale with a value of $1=$ very disagreeable to $5=$ strongly agree. Furthermore, this instrument was tested for validity and reliability statistically using validity and reliability. The questionnaire was designed using question instruments that had been made from previous research (Chaouch, 2017; Hossain, 2017).

Results:

\section{Demographic Profile}

In this study, out of 700 questionnaires were distributed to respondents in 3 regions in Papua Province, comprise of Jayapura City, Jayapura Regency, and Kerom Regency. Only 683 were returned to the researcher. The demographic background of the respondents consisted of age, gender, religion, education level and income level. Table 1 shows the demographic profile of the respondents in this study.

Table 1. Respondents Demographic Profile

\begin{tabular}{|lcccc|}
\hline Category & $\begin{array}{l}\text { Jayapura } \\
\text { City }\end{array}$ & $\begin{array}{l}\text { Jayapura } \\
\text { Regency }\end{array}$ & $\begin{array}{l}\text { Kerom } \\
\text { Regency }\end{array}$ & Frequency \\
\hline Age & 20 & 43 & 37 & 100 \\
$<25$ years & 144 & 183 & 54 & 381 \\
$25-35$ years & 29 & 76 & 91 & 196 \\
$36-50$ years & 0 & 0 & 6 & 6 \\
$>50$ years & $\mathbf{1 9 3}$ & $\mathbf{3 0 2}$ & $\mathbf{1 8 8}$ & $\mathbf{6 8 3}$ \\
\hline Total & & & & \\
\hline Gender & 86 & 158 & 103 & 347 \\
Male & 107 & 144 & 85 & 336 \\
Female & $\mathbf{1 9 3}$ & $\mathbf{3 0 2}$ & $\mathbf{1 8 8}$ & $\mathbf{6 8 3}$ \\
\hline Total & & & & \\
\hline Religion & 79 & 188 & 185 & 452 \\
Muslim & 114 & 114 & 3 & 231 \\
Non-Muslim & $\mathbf{1 9 3}$ & $\mathbf{3 0 2}$ & $\mathbf{1 8 8}$ & $\mathbf{6 8 3}$ \\
\hline Total & & & & \\
\hline Marital Status & 87 & 150 & 65 & 381 \\
Single & 106 & 152 & 123 & 302 \\
Married/Have Married & $\mathbf{1 9 3}$ & $\mathbf{3 0 2}$ & $\mathbf{1 8 8}$ & $\mathbf{6 8 3}$ \\
\hline Total & & & & \\
\hline
\end{tabular}




\begin{tabular}{|c|c|c|c|c|}
\hline \multicolumn{5}{|l|}{ Education Level } \\
\hline SD, SMP, SMA (Primary - & 20 & 139 & 166 & 325 \\
\hline Secondary) & 0 & 7 & 6 & 13 \\
\hline Diploma/College & 173 & 156 & 16 & 345 \\
\hline University & 0 & 0 & 0 & 0 \\
\hline \multicolumn{5}{|l|}{ Lainnya } \\
\hline Total & 193 & 302 & 188 & 683 \\
\hline \multicolumn{5}{|l|}{ Monthly Salary } \\
\hline$<3.000 .000$ & 24 & 20 & 149 & 193 \\
\hline $3.000 .000-5.000 .000$ & 163 & 264 & 38 & 465 \\
\hline $5.000 .000-10.000 .000$ & 6 & 18 & 1 & 24 \\
\hline$>10.000 .000$ & 0 & 0 & 0 & 0 \\
\hline Total & 193 & 302 & 188 & 683 \\
\hline
\end{tabular}

Based on table 2 it can be seen that out of 683 respondents, around $56 \%$ of the respondents were 25-35 years old or 381 respondents, while 196 respondents (around 29\%) were aged between $36-50$ years and $14 \%$ of the total respondents are less than 25 years old, while $1 \%$ of the total respondents is over 50 years old. Meanwhile, it also can be concluded that there were more male respondents than the female. Around $51 \%$ of the respondents were male and $49 \%$ were female. Moreover, based on the characteristics of religion, respondents who are Muslim are as much as $66 \%$ or around 452 respondents while the rest are non-Muslims which is about $34 \%$ or 231 respondents.

The demographic profile also indicates that around $56 \%$ of the respondents or 381 respondents are unmarried, while those who had or had been married were the rest or around $44 \%$. In this study, there are 345 of the total respondents with last education in university level, while $48 \%$ of the respondents had the last education in elementary, middle or junior high school or around 325 respondents. Meanwhile, only $2 \%$ or 13 respondents attended diploma schools. In addition, there are $68 \%$ of the respondents with income between 3-5 million, while those who earn less than 3 million are around $28 \%$ and those with income of 5-10 million are around 4\%.

\section{Analysis}

\subsection{Knowledge About Islamic Banking}

\subsubsection{Correlation between Knowledge and Religion}

As shown in table 2 there are 452 respondents who are Muslim and out of 231 respondents are non-Muslim. In general, more respondents know about the Islamic bank. Out of 416 Muslim respondents (92\%) know about the existence of Islamic banks, while 36 respondents $(8 \%)$ do not know about Islamic banking. Also, there were 223 (96\%) non-Muslim respondents who were aware of the existence of Islamic banks and 8 respondents (4\%) who did not know about the Islamic banking. In addition, based on the crosstab test, it is indicated that there is a correlation between religion and respondents' knowledge about 
Islamic banks. The Chi-Square value is 5.139 with a significance of 0.023 or $<0.05$ reveals that there is a correlation.

Table 2. Statistic Descriptive of Knowledge

\begin{tabular}{|c|c|c|c|c|c|}
\hline \multirow{2}{*}{ Question } & \multirow{2}{*}{ Religion } & \multicolumn{2}{|c|}{ Answer } & \multirow{2}{*}{$\begin{array}{l}\text { Chi- } \\
\text { Square } \\
\text { Value }\end{array}$} & \multirow{2}{*}{ Sig. } \\
\hline & & Yes & No & & \\
\hline $\begin{array}{l}\text { Do you know about } \\
\text { Islamic bank? }\end{array}$ & Non-Muslim & 416 & 36 & 5.139 & 0.023 \\
\hline
\end{tabular}

\subsubsection{Knowledge About Product and Service of Islamic Banking}

Generally, as shown in fig(s).1, saving product is the most widely known by customers while financing product provided by the Islamic banking is the least known. Around 63\% of the respondents know about savings products, while only $11 \%$ of the respondents know about financing products. Other products known by the customers are investment products and other service products.

Figure 1. Knowledge of Islamic Banking Product and Service

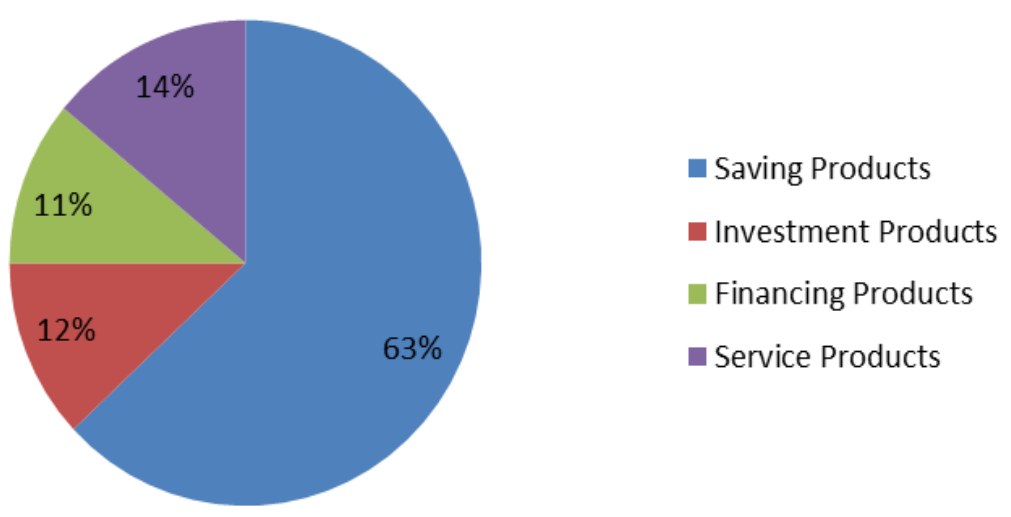

This study also reveals the source used by the respondents to gain information about Islamic bank. Based on the survey, most of the respondents get the information about Islamic banking from Islamic bank itself. Around 30\% of respondents choose Islamic bank as the source of information. Meanwhile, around $22 \%$ of the respondents used social media as the source of information and $18 \%$ of the respondents get information about Islamic banking by searching on the internet. There are also $16 \%$ of the respondents choose television and $7 \%$ of the respondents pick mass media (such as newspaper) as the source of information about Islamic banking. The influence of other people also can be considered as the source of Islamic banking information, since $7 \%$ of the respondents get the information from their friends. 
Table 3. Source of Information about Islamic Banking

\begin{tabular}{|c|c|c|c|c|c|c|}
\hline \multirow{2}{*}{ Questions } & \multicolumn{5}{|c|}{ Answer } \\
\cline { 2 - 7 } & $\begin{array}{c}\text { Islamic } \\
\text { Bank }\end{array}$ & $\begin{array}{c}\text { Social } \\
\text { Media }\end{array}$ & Internet & $\begin{array}{c}\text { Mass } \\
\text { Media }\end{array}$ & TV & Friends \\
\hline $\begin{array}{l}\text { Where did you } \\
\text { find out about } \\
\text { Islamic bank? }\end{array}$ & $30 \%$ & $22 \%$ & $18 \%$ & $7 \%$ & $16 \%$ & $7 \%$ \\
\hline
\end{tabular}

\subsection{Understanding of Islamic Banking}

\subsubsection{Understanding of Islamic Banking Financial Instruments}

The survey result indicated that most of the respondents, both Muslims and non-Muslims do not understand the financial instruments provided by Islamic banking, which consist of wadiah, murabaha, mudharabah, musyarakah, salam, ijarah and istishna. Generally, $90 \%$ of respondents answer "no" when asked about these terms. In addition, there are three financial instruments of Islamic banks that mostly known by the respondents, namely wadiah, mudharabah and murabaha, while musyarakah, salam, istishna and ijarah were the least known by the respondents.

The study also investigated the correlation between religion and the understanding of Islamic bank financial instruments. The crosstab test result indicated a number of differences. The descriptive statistics show that there is a correlation between religion and understanding of wadiah, murabaha, mudharabah and salam instruments. It can be seen by the value of Chi-Square test $<0.05$, while the test indicated that there is no correlation between religion and understanding of musyarakah, ijarah and istishna instruments, because the value of Chi-Square test is $>0.05$. Tabel 4 illustrates the correlation between religion and understanding of Islamic banking financial instruments. 
Table 4. Understanding of Islamic Banking Financial Instruments

\begin{tabular}{|c|c|c|c|c|c|c|}
\hline \multirow[b]{2}{*}{ Questions } & \multirow{2}{*}{$\begin{array}{c}\text { Financial } \\
\text { Instruments }\end{array}$} & \multicolumn{2}{|c|}{ Answer } & \multirow{2}{*}{$\begin{array}{c}\text { Value of } \\
\text { Chi Square } \\
\text { Test }\end{array}$} & \multirow{2}{*}{ Sig. } & \multirow{2}{*}{ Religion } \\
\hline & & Yes & No & & & \\
\hline \multirow{7}{*}{$\begin{array}{l}\text { Do you know } \\
\text { about these } \\
\text { financial } \\
\text { instruments } \\
\text { provided by } \\
\text { Islamic bank? }\end{array}$} & Wadiah & $\begin{array}{l}73 \\
22\end{array}$ & $\begin{array}{l}379 \\
209\end{array}$ & 5.606 & 0.018 & $\begin{array}{l}\text { Muslim } \\
\text { Non-Muslim }\end{array}$ \\
\hline & Murabahah & $\begin{array}{l}24 \\
2\end{array}$ & $\begin{array}{l}428 \\
229\end{array}$ & 8.245 & 0.004 & $\begin{array}{l}\text { Muslim } \\
\text { Non-Muslim }\end{array}$ \\
\hline & Mudharabah & $\begin{array}{c}26 \\
6\end{array}$ & $\begin{array}{l}426 \\
225\end{array}$ & 3.407 & 0.065 & $\begin{array}{l}\text { Muslim } \\
\text { Non-Muslim }\end{array}$ \\
\hline & Musyarakah & $\begin{array}{l}12 \\
5\end{array}$ & $\begin{array}{l}440 \\
226\end{array}$ & 1.151 & 0.697 & $\begin{array}{l}\text { Muslim } \\
\text { Non-Muslim }\end{array}$ \\
\hline & Salam & $\begin{array}{c}13 \\
2\end{array}$ & $\begin{array}{l}439 \\
229\end{array}$ & 2.876 & 0.090 & $\begin{array}{l}\text { Muslim } \\
\text { Non-Muslim }\end{array}$ \\
\hline & Ijarah & $\begin{array}{l}15 \\
5\end{array}$ & $\begin{array}{l}437 \\
226\end{array}$ & 0.716 & 0.397 & $\begin{array}{l}\text { Muslim } \\
\text { Non-Muslim }\end{array}$ \\
\hline & Istishna & $\begin{array}{l}9 \\
1\end{array}$ & $\begin{array}{l}443 \\
230\end{array}$ & 2.573 & 0.109 & $\begin{array}{l}\text { Muslim } \\
\text { Non-Muslim }\end{array}$ \\
\hline
\end{tabular}

\subsubsection{Understanding about Islamic Banking Operational System}

\subsubsection{Islamic Banking Runs Its Operations Based on Sharia Law.}

As shown in table 5, there is a correlation between religion and customer understanding of Islamic banking operational legal basis, including Qur'an and Hadith. The value of ChiSquare test is 65,773 with a significance of $0,000<0.05$. It indicates that there is correlation between the two variables. The survey conducted also shows that $47 \%$ of Muslim respondents agree as well as $35 \%$ of Muslim respondents strongly agree that Islamic banking runs its operations based on Sharia law. Meanwhile, 55\% and $10 \%$ of the nonMuslim respondents agree and strongly agree that Islamic banking runs its operations based on Sharia law respectively, while $34 \%$ of the respondents are neutral regarding the statement. In addition, the mean value obtained is 4.01 with a standard deviation of 0.765 indicates that the customers have a good understanding of the legal basis of Islamic banks. 


\subsubsection{Islamic Banks Can Be Used by Both Muslims and non-Muslims.}

Based on the results of the study, it is indicated that there is a correlation between religion and customers' understanding of Islamic banking customer target (Muslims and nonMuslims). The Chi-Square test value of 33,041 with a significance of 0,000 $<0.05$ reveals that there is a correlation. In addition, the survey also shows that $50 \%$ of respondents who were Muslim agree and $20 \%$ of the Muslim respondents strongly agreed regarding Islamic banking customer target. Meanwhile, there are $58 \%$ of non-Muslim respondents who agree $25 \%$ of them strongly agree that Islamic banking can be used by both Muslims and nonMuslims. In general, the respondents have a good understanding of the universality of Islamic banking, which is indicated by the mean value obtained is equal to 3.84 with a standard deviation of 0.933 .

\subsubsection{Islamic Banks Prohibit All Forms of Usury in Their Operational Activities and} Transactions.

The results of the descriptive statistics show that there is a correlation between religion and understanding of Islamic banking in prohibiting usury, since the Chi-Square test value is 58,180 with a significance of $0,000<0.05$. In addition, the survey of 683 respondents indicated that $50 \%$ of Muslim respondents agree and $17 \%$ of Muslim respondents strongly agree that usury is prohibited in Islamic banking activities. Meanwhile, there are $41 \%$ of non-Muslim respondents and 5\% of non-Muslim respondents respectively agree and strongly agree. Generally, it can be concluded that the respondents have a good understanding about the usury prohibition of Islamic banks, since the mean obtained is equal to 3.66 with a standard deviation of 0.831 .

\subsubsection{Profits in Islamic Banks are Obtained Based on The Profit-Sharing System, Not} Interest.

The Chi-Square test value of 31.001 with a significance of $0.000<0.05$ indicates that there is a correlation between religion and understanding of Islamic banking profit-sharing system. Furthermore, the survey of 683 respondents also showed that 53\% of the Muslim respondents agree and $23 \%$ of the Muslim respondents strongly agree that profits gained by Islamic banks are obtained based on the profit-sharing system, not interest. Meanwhile, nonMuslim respondents who chose to agree were around $51 \%$ and $10 \%$ of the non-Muslim respondents strongly agree. In conclusion, the respondents have a good understanding that Islamic banks gain their profit using the profit-sharing system. It is indicated by the mean value obtained is equal to 3.85 with a standard deviation of 0.7689 . 
Ira Eka Pratiwi, Fachrudin Fiqri Affandy

Table 5. Understanding of Islamic Banking

\begin{tabular}{|c|c|c|c|c|c|c|c|c|c|c|c|c|c|}
\hline No & Statements & SNA & NA & $\mathbf{N}$ & A & SA & Min & Max & Mean & $\begin{array}{l}\text { Dev. } \\
\text { Std. } \\
\text { Value }\end{array}$ & $\begin{array}{c}\text { Value of } \\
\text { Chi } \\
\text { Square } \\
\text { Test }\end{array}$ & Sig. & Religion \\
\hline 1 & $\begin{array}{l}\text { Islamic banking runs } \\
\text { its operations based } \\
\text { on Sharia law. }\end{array}$ & $\begin{array}{l}1 \% \\
0 \%\end{array}$ & $\begin{array}{l}1 \% \\
1 \%\end{array}$ & $\begin{array}{l}16 \% \\
34 \%\end{array}$ & $\begin{array}{l}47 \% \\
55 \%\end{array}$ & $\begin{array}{l}35 \% \\
10 \%\end{array}$ & 1 & 5 & 4.01 & 0.765 & 65.773 & 0.000 & $\begin{array}{l}\text { Muslim } \\
\text { Non-Muslim }\end{array}$ \\
\hline 2 & $\begin{array}{l}\text { Islamic banking can } \\
\text { be used by both } \\
\text { Muslims and non- } \\
\text { Muslims. }\end{array}$ & $0 \%$ & $1 \%$ & $\begin{array}{l}13 \% \\
16 \%\end{array}$ & $\begin{array}{l}50 \% \\
58 \%\end{array}$ & $\begin{array}{l}20 \% \\
25 \%\end{array}$ & 1 & 5 & 3.84 & 0.933 & 33.041 & 0.000 & $\begin{array}{l}\text { Muslim } \\
\text { Non-Muslim }\end{array}$ \\
\hline 3 & $\begin{array}{l}\text { Islamic banking } \\
\text { prohibit all forms of } \\
\text { usury in their } \\
\text { operational activities } \\
\text { and transactions. }\end{array}$ & $4 \%$ & $2 \%$ & $\begin{array}{l}27 \% \\
52 \%\end{array}$ & $\begin{array}{l}50 \% \\
41 \%\end{array}$ & $\begin{array}{r}17 \% \\
5 \%\end{array}$ & 1 & 5 & 3.66 & 0.831 & 58.180 & 0.000 & $\begin{array}{l}\text { Muslim } \\
\text { Non-Muslim }\end{array}$ \\
\hline 4 & $\begin{array}{l}\text { Profits in Islamic } \\
\text { banking are obtained } \\
\text { based on the profit- }\end{array}$ & $2 \%$ & $1 \%$ & $22 \%$ & $53 \%$ & $23 \%$ & 1 & 5 & 3.85 & 0.769 & 31.001 & 0.000 & Muslim \\
\hline
\end{tabular}




\begin{tabular}{|c|c|c|c|c|c|c|c|c|c|c|c|c|c|}
\hline & $\begin{array}{l}\text { sharing system, not } \\
\text { interest. }\end{array}$ & $0 \%$ & $2 \%$ & $37 \%$ & $51 \%$ & $10 \%$ & & & & & & & Non-Muslim \\
\hline 5 & $\begin{array}{l}\text { Islamic banking } \\
\text { prohibits all forms of } \\
\text { uncertain } \\
\text { transactions. }\end{array}$ & $\begin{array}{l}1 \% \\
0 \%\end{array}$ & $\begin{array}{l}0 \% \\
0 \%\end{array}$ & $\begin{array}{l}17 \% \\
32 \%\end{array}$ & $\begin{array}{l}58 \% \\
53 \%\end{array}$ & $\begin{array}{r}23 \% \\
15 \%\end{array}$ & 1 & 5 & 3.95 & 0.708 & 23.120 & 0.000 & $\begin{array}{l}\text { Muslim } \\
\text { Non-Muslim }\end{array}$ \\
\hline 6 & $\begin{array}{l}\text { Islamic bank only } \\
\text { invests in halal } \\
\text { businesses that do } \\
\text { not violate sharia } \\
\text { law. }\end{array}$ & $\begin{array}{l}1 \% \\
0 \%\end{array}$ & $4 \%$ & $\begin{array}{l}13 \% \\
32 \%\end{array}$ & $\begin{array}{l}64 \% \\
61 \%\end{array}$ & $\begin{array}{r}18 \% \\
7 \%\end{array}$ & 1 & 5 & 3.89 & 0.697 & 51.690 & 0.000 & $\begin{array}{l}\text { Muslim } \\
\text { Non-Muslim }\end{array}$ \\
\hline 7 & $\begin{array}{l}\text { Each Islamic banking } \\
\text { has a Sharia } \\
\text { Supervisory Board } \\
\text { that oversees all } \\
\text { forms of activities in } \\
\text { accordance with } \\
\text { sharia compliance }\end{array}$ & $1 \%$ & $0 \%$ & $20 \%$ & $64 \%$ & $\begin{array}{l}15 \% \\
6 \%\end{array}$ & 1 & 5 & 3.80 & 0.666 & 56.614 & 0.000 & $\begin{array}{l}\text { Muslim } \\
\text { Non-Muslim }\end{array}$ \\
\hline
\end{tabular}

Note: (SDA=Strongly Disagree, DA=Disgree, $\mathrm{N}=$ Neutral, A=Agree, SA=Strongly Agree) 


\subsubsection{Islamic Banking Prohibits All Forms of Uncertain Transactions.}

Based on the results of the study, there is a correlation between religion and understanding of Islamic banking transaction that does not carry out an uncertain (gharar) transaction. It is shown by the value of the Chi-Square test which is 23,120 with a significance of $0,000<0.05$. In addition, the survey also shows that $58 \%$ of the Muslim respondents agree and $23 \%$ of Muslim respondents strongly agree that all forms of uncertain transactions are banned by Islamic banking activities. There are also 53\% of non-Muslim respondents and $15 \%$ of non-Muslims respectively agree and strongly agree about it. In sum, the mean value obtained is 3.95 with a standard deviation of 0.708 indicating that the respondents have a good understanding that Islamic banking does not perform uncertain transactions.

\subsubsection{Islamic Bank Only Invests in Halal Businesses That Do Not Violate Sharia} Law.

The results showed that there is a correlation between religion and understanding of Islamic banking investment that is in accordance with sharia law. It can be seen by the value of the Chi-Square test which is 51,690 with a significance of $0,000<0.05$. The survey also reveals that $64 \%$ of the Muslim respondents and $15 \%$ of Muslim respondents respectively agree and strongly agree that Islamic banking only invests in a halal business that do not violate Sharia law. Meanwhile, there are $61 \%$ and $7 \%$ of non-Muslim respondents successively agree and strongly agree about it. In addition, it can be summarized that the respondents have a good understanding that Islamic banking only invests in a business that is in accordance with Sharia law. The mean value obtained is equal to 3.89 with a standard deviation of 0.697 .

\subsubsection{Each Islamic Banking Has A Sharia Supervisory Board That Oversees All Forms of Activities in Accordance with Sharia Compliance}

Based on the results of the study it is known that there is a correlation between religion and understanding of Sharia Supervisory Board in Islamic banking. It is indicated by the Chi-Square test value of 56,614 with a significance of 0,000 $<0.05$. Meanwhile, the survey also reveals that $64 \%$ of Muslim respondents agree and 15\% of Muslim respondents strongly agree that Islamic banking has a Sharia Supervisory Board that oversees all forms of activities in accordance with sharia compliance, while $48 \%$ of nonMuslim respondents agree and $6 \%$ of non-Muslim respondents strongly agree regarding this statement. In addition, generally, the mean value obtained is equal to 3.80 with a standard deviation of 0.666 indicating that the respondents have a good understanding that Islamic banks do not make uncertain transactions. 


\subsection{Perception Towards Islamic Banking}

\subsubsection{Islamic Banks Have A Great Potential to Develop in Indonesia.}

The results findings shown the value of the Chi-Square test which is 65,773 with a significance of $0,000<0.05$ suggest that there is a correlation between religion and the perception of the respondents regarding the potential of Islamic banking growth in Indonesia. In addition, the survey of 683 respondents also showed that $55 \%$ of Muslim respondents agree and 35\% of Muslim respondents strongly agree that Islamic banking has a great potential to develop in Indonesia. Meanwhile, 59\% of non-Muslim respondents agree and $22 \%$ of non-Muslim respondents strongly agree about this. Moreover, the mean value obtained is 4.16 with a standard deviation of 0.689 suggest that the respondents having a positive perception of the growth potential of Islamic banking in Indonesia.

\subsubsection{Islamic Banks Have A Potential to Develop in Papua.}

One major finding from the study reveals that there is no correlation between religion and customer perception about the potential growth of Islamic banking in Papua. It is indicated by Chi-Square test value which is 33,041 with a significance of $0.068>0.05$. The survey also reveals that from 683 respondents, $65 \%$ of Muslim respondents, as well as $68 \%$ of non-Muslim respondents, agree that Islamic banks have the potential to grow in Papua province. Meanwhile, $18 \%$ of Muslim respondents and 13\% of non-Muslim respondents strongly agree about that. The mean value obtained is equal to 3.95 with a standard deviation of 0.662 also indicate that the respondents have a positive perception that Islamic banks have the potential to develop in Papua.

\subsubsection{Islamic Banks Have Ability to Compete in a Healthy Manner with Conventional Banks.}

The crosstab test finds that there is no correlation between religion and the consumer perception of the competition between Islamic banks and conventional banks. The ChiSquare test value is 58,180 with a significance of $0.064>0.05$. In addition, the respondents also believe that Islamic banks can compete in a healthy manner with conventional banks. There are $66 \%$ of Muslim respondents and $74 \%$ non-Muslim respondents agree about the ability of Islamic banking to compete with conventional banks, while $19 \%$ of Muslim respondents, as well as 13\% of non-Muslim respondents, strongly agree. Moreover, the mean value obtained is 4.01 with a standard deviation of 0.615 indicates that the respondents have a positive perception of the competition between the two types of banks. 


\subsubsection{Islamic Banking Products are Different from Conventional Bank Products.}

Based on the result findings, it can be suggested that there is a correlation between religion and the perception of the customer about the differences between Islamic banking products and conventional banking products. The value of the Chi-Square test is 31,001 with a significance of $0,000<0.05$. The survey also reveals that mostly the respondent agree that there are several differences between products in Islamic banking and conventional banking. Around 58\% of Muslim respondents and $42 \%$ of non-Muslim respondents agree, while $8 \%$ of Muslim respondents and 3\% of nonMuslim respondents strongly agree regarding this. However, the survey also reveals that $51 \%$ of non-Muslim respondents choose neutral. It means that they could not decide whether Islamic banking has a difference between conventional banking or no. Moreover, the findings also suggest the respondents have a positive perception about the products differences between the two banks.

\subsubsection{Islamic Banks Have Not Optimally Marketed Their Products to The Public.}

Based on the findings, it is believed by the respondents that Islamic banks have not optimally marketed their products to the public. The Chi-Square test is 23,180 with a significance of $0.124>0.05$ means that there is no correlation between religion and the customers' perception of how Islamic banking marketed their products. The survey of 683 respondents also showed that $66 \%$ of Muslims respondents and $74 \%$ of nonMuslim respondents agree, while 21\% of Muslim respondents and 18\% of non-Muslim respondents strongly agree regarding the statement. In addition, the mean value is 4.07 with a standard deviation of 0.626 suggests that the respondents have a positive perception of the marketing of Islamic banking products.

\subsubsection{Islamic Banks Services are More Satisfactory Compared to Conventional Banks.}

The results of the study suggest that there is a correlation between religion and the respondents' perception of Islamic banks services. The Chi-Square test value is 51,690 with significance 0.001 which is higher than 0.05 indicates the correlation. One major finding of the survey suggests that $55 \%$ of Muslim respondents and $45 \%$ of nonMuslim respondents agree, while $6 \%$ both Muslim and non-Muslim respondents strongly agree that services provided by Islamic banking are more satisfied compared to conventional banking. However, there is an interesting fact reveals that $46 \%$ of nonMuslim respondents choose neutral regarding this issue. It assumes that they could not make any comparison between service in Islamic banking and conventional banking. In addition, the mean value obtained is 3.58 with a standard deviation of 0.719 indicates that the respondents have a good and positive perception of Islamic bank services. 


\subsubsection{Profit Sharing Provided by Islamic Bank Savings is Higher than The Savings Interest Given by Conventional Banks.}

The results of the study shown the Chi-Square test value is 56,614 with a significance of $0,000<0.05$. It indicates that there is correlation between religion and perception of profit sharing provided by Islamic banking. The survey of 683 respondents also suggests that $50 \%$ of Muslim respondents and $34 \%$ of non-Muslim respondents agree, while $5 \%$ of Muslim respondents and $2 \%$ of non-Muslim respondents strongly agree that profit sharing provided by Islamic bank savings is higher that the savings interest given by conventional banks. The survey also finds that $41 \%$ of Muslim respondents and $63 \%$ of non-Muslim respondents are neutral. It indicates that they are not able to decide whether profit sharing provided by Islamic banks saving product is higher than the interest given by conventional banks or not. In addition, the mean value obtained is equal to 3.49 with a standard deviation of 0.653 suggest that the respondents have a positive perception about profit sharing provided by Islamic bank savings. 
Ira Eka Pratiwi, Fachrudin Fiqri Affandy

Table 6. Perception towards Islamic banking

\begin{tabular}{|c|c|c|c|c|c|c|c|c|c|c|c|c|c|}
\hline No & Statements & SDA & DA & $\mathbf{N}$ & A & SA & Min & Max & Mean & $\begin{array}{l}\text { Std. } \\
\text { Dev. } \\
\text { Value }\end{array}$ & $\begin{array}{l}\text { Chi } \\
\text { Square } \\
\text { Test } \\
\text { Value }\end{array}$ & Sig. & Religion \\
\hline 1 & $\begin{array}{l}\text { Islamic banks have a } \\
\text { great potential to } \\
\text { develop in } \\
\text { Indonesia. }\end{array}$ & $\begin{array}{l}1 \% \\
0 \%\end{array}$ & $\begin{array}{l}0 \% \\
0 \%\end{array}$ & $\begin{array}{r}9 \% \\
19 \%\end{array}$ & $\begin{array}{r}55 \% \\
59 \%\end{array}$ & $\begin{array}{l}35 \% \\
22 \%\end{array}$ & 1 & 5 & 4.16 & 0.689 & 24.137 & 0.000 & $\begin{array}{l}\text { Muslim } \\
\text { Non-Muslim }\end{array}$ \\
\hline 2 & $\begin{array}{l}\text { Islamic banks have a } \\
\text { potential to develop } \\
\text { in Papua. }\end{array}$ & $\begin{array}{l}1 \% \\
0 \%\end{array}$ & $\begin{array}{l}2 \% \\
0 \%\end{array}$ & $\begin{array}{l}17 \% \\
18 \%\end{array}$ & $\begin{array}{l}63 \% \\
68 \%\end{array}$ & $\begin{array}{l}18 \% \\
13 \%\end{array}$ & 1 & 5 & 3.95 & 0.662 & 8.754 & 0.068 & $\begin{array}{l}\text { Muslim } \\
\text { Non-Muslim }\end{array}$ \\
\hline 3 & $\begin{array}{l}\text { Islamic banks have } \\
\text { ability to compete in } \\
\text { a healthy manner } \\
\text { with conventional } \\
\text { banks }\end{array}$ & $1 \%$ & $0 \%$ & $\begin{array}{l}13 \% \\
13 \%\end{array}$ & $66 \%$ & $\begin{array}{l}19 \% \\
13 \%\end{array}$ & 1 & 5 & 4.01 & 0.615 & 8.878 & 0.064 & $\begin{array}{l}\text { Muslim } \\
\text { Non-Muslim }\end{array}$ \\
\hline 4 & $\begin{array}{l}\text { Islamic banking } \\
\text { products are } \\
\text { different from }\end{array}$ & $1 \%$ & $7 \%$ & $25 \%$ & $58 \%$ & $8 \%$ & 1 & 5 & 3.57 & 0.744 & 47.124 & 0.000 & Muslim \\
\hline
\end{tabular}




\begin{tabular}{|c|c|c|c|c|c|c|c|c|c|c|c|c|c|}
\hline & $\begin{array}{l}\text { Conventional Bank } \\
\text { products. }\end{array}$ & $0 \%$ & $5 \%$ & $51 \%$ & $42 \%$ & $3 \%$ & & & & & & & Non-Muslim \\
\hline 5 & $\begin{array}{l}\text { Islamic banks have } \\
\text { not optimally } \\
\text { marketed their } \\
\text { products to the } \\
\text { public. }\end{array}$ & $\begin{array}{l}1 \% \\
0 \%\end{array}$ & $\begin{array}{l}1 \% \\
0 \%\end{array}$ & $\begin{array}{l}10 \% \\
7 \%\end{array}$ & $\begin{array}{r}66 \% \\
74 \%\end{array}$ & $\begin{array}{l}21 \% \\
18 \%\end{array}$ & 1 & 5 & 4.07 & 0.626 & 7.239 & 0.124 & $\begin{array}{l}\text { Muslim } \\
\text { Non-Muslim }\end{array}$ \\
\hline 6 & $\begin{array}{l}\text { Islamic Banks } \\
\text { services are more } \\
\text { satisfactory } \\
\text { compared to } \\
\text { Conventional Banks. }\end{array}$ & $\begin{array}{l}2 \% \\
0 \%\end{array}$ & $\begin{array}{l}5 \% \\
1 \%\end{array}$ & $\begin{array}{l}33 \% \\
46 \%\end{array}$ & $\begin{array}{r}55 \% \\
45 \%\end{array}$ & $\begin{array}{l}6 \% \\
6 \%\end{array}$ & 1 & 5 & 3.58 & 0.719 & 18.246 & 0.001 & $\begin{array}{l}\text { Muslim } \\
\text { Non-Muslim }\end{array}$ \\
\hline 7 & $\begin{array}{l}\text { Profit sharing } \\
\text { provided by Islamic } \\
\text { Bank savings is } \\
\text { higher than the } \\
\text { savings interest } \\
\text { given by } \\
\text { Conventional Banks. }\end{array}$ & $\begin{array}{l}2 \% \\
0 \%\end{array}$ & $\begin{array}{l}2 \% \\
1 \%\end{array}$ & $\begin{array}{l}41 \% \\
63 \%\end{array}$ & $\begin{array}{r}50 \% \\
34 \%\end{array}$ & $\begin{array}{l}5 \% \\
2 \%\end{array}$ & 1 & 5 & 3.49 & 0.653 & 33.492 & 0.000 & $\begin{array}{l}\text { Muslim } \\
\text { Non-Muslim }\end{array}$ \\
\hline
\end{tabular}

Note: (SDA=Strongly Disagree, DA=Disagree, N=Neutral, A=Agree, SA=Strongly Agree) 


\section{Conclusion}

This research is conducted to investigate the knowledge and perception of Muslim and nonMuslim customers about the products and services provided by Islamic banking in Papua Province, one of the regions in Indonesia with the minority Muslim population. In general, the study reveals that both Muslims and non-Muslims know about the existence of Islamic banking and there is a correlation between religion and respondents' knowledge of Islamic banking. Meanwhile, the survey results suggest that the most widely known Islamic banking product is saving products and mainly, they get information about Islamic banking from social media, internet, and Islamic bank itself.

Although most of the respondents had known about the Islamic banking, relatively they do not understand about the Islamic banking financial instruments provided by Islamic banks, such as Wadiah, Mudharabah, Murabahah, Musyarakah, Ijarah, Istishna, and Salam. Furthermore, the study also finds that Muslim and non-Muslim customers have a good level of understanding about Islamic banking basic principles, such as the Sharia law as the based of Islamic banking operation, the universal customers, the prohibition of usury and uncertain transaction, as well as the profit-sharing system.

In addition, the results of the study also reveal that both Muslim and non-Muslims have a positive perception of Islamic banks. It also found that religious factors correlate with perception of the respondents of the potential of Islamic banks to develop in Indonesia as general and Papua as specific, as well as their perception of Islamic banking's competition and differences with conventional banks, the optimization of products marketing, satisfaction indicator, and the ratio of profit sharing provided by Islamic banking.

Regarding the results of this paper, there are several recommendations proposed for enlarging the market share of Islamic banking. First, even though the existence of Islamic bank has been known generally by the people, here are still several Islamic banking products and services unknown by the customers. It could be because of the Arabic term used by the Islamic banking, such as Wadiah, Mudharabah, Murabahah, Musyarakah, Ijarah, Istishna, and Salam. Thus, products and services socialization could impact the level of understanding of the customers both Muslims and non-Muslims towards Islamic banking. Second, it is also proposed to develop new product and increase the service quality of Islamic banking. So, it could positively increase the perception of Muslim and non-Muslim customers about Islamic banking. In addition, it is also need to conduct further research to compare the level of understanding and perception of Muslims and non-Muslims towards Islamic banking. 


\section{References}

Akbar, S. S. Z. A., \& Kalmadi, S. (2012). An Investigation of User Perceptions of Islamic Banking Practices in the United Kingdom. International Journal of Islamic and Middle Eastern Finance and Management, 5(4).

Antonio, M. S. (2001). Islamic Banking, Bank Syariah dari Teori ke Praktik. Jakarta: Gema Insani.

Buchari, I., Rafiki, A.,\& Al Qassab, M. A. H. (2015). Awareness and Attitudes of Employees towards Islamic Banking Products in Bahrain. Procedia Economics and Finance, 30.

Bujang, M. A., Sa'at, N., \& Sidik, T. M. I. T. A. B. (2017). Determination of Minimum Sample Size Requirement for Multiple Linear Regression and Analysis of Covariance Based on Experimental and Non-experimental Studies. Epidiemiology Biostatistics and Public Health Journal, 14(3).

Chaouch, N. (2017). An Exploratory Study of Tunisian Customers' Awareness and Perception of Islamic banks. International Journal of Islamic Economics and Finance Studies, 3(2).

Ferdinand, A. (2005). Structural Equation Modelling Dalam Penelitian Manajemen: Aplikasi Modelmodel Rumit dalam Penelitian untuk Tesis Magister dan Disertasi Doktor. Semarang: Badan Penerbit Universitas Diponegoro.

Given, L.M. (Ed). (2008). The Sage Encyclopedia of Qualitative Research Methods. California: SAGE Publication, Inc.

Hossain, Md. A, \& Roy, B. N. (2017) Perception of Non-Muslim Customers towards Islamic Banking: A Study in Northern Part of Bangladesh. Global Journal of Human Social Science: E Economics, 17(5).

Huda, N., \& Heykal, M. (2010). Lembaga Keuangan Islam: Tinjauan Teoritis dan Praktis. Jakarta: Kencana Prenada Media Group.

Karim, A. (2001). Bankir Yahudi pada Zaman Abbasiyah: Ekonomi Islam Suatu Kajian Kontemporer. Jakarta: Gema Insani Press.

Nachrowi, N. D., \& Usman, H. (2008). Penggunaan Teknik Ekonometri (Edisi Revisi). Jakarta: PT. RajaGrafindo Persada.

Rahman, N. UR. (2012). Attitude of Muslims towards Islamic Banking and Finance in the North West of England: A Socio-Economic Perspective. Durham theses, Durham University.

Ringim, K. J. (2014). Perception of Nigerian Muslim Account Holders in Conventional Banks toward Islamic Banking Products. International Journal of Islamic and Middle Eastern Finance and Management, 7(3). 
Saiti, B. (2015). The Awareness and Attitude towards Islamic Banking: A Study in Malaysia. Global Review of Islamic Economics and Business, 2(3).

Soud, N. S., \& Sayilir, O. Perceptions of Islamic Banking Among Muslim and Non-Muslim Citizens in Tanzania. International Journal of Islamic Economics and Finance Studies, 3(3).

Sugiyono. (2016). Metode Penelitian Kuantitatif, Kualitatif $\mathcal{E} R$ dan D. Bandung: Alfabeta.

Ul Islam, J., \& Rahman, Z. (2016). Awareness and Willingness towards Islamic Banking among Muslims: An Indian perspective. International Journal of Islamic and Middle Eastern Finance and Management, 10(1).

Wan Omar, W. A., \& Rahim, H. A. (2016). Perception of non-Muslims towards Islamic Banking Revisited: SEM approach. Mediterranean Journal of Social Science, 7(1). 